\title{
Financing of Growth Through Self-Assessment Governance and Total Quality Growth Model
}

\section{J D Agarwal," Aman Agarwal" and Yamini Agarwal}

\author{
The authors gratefully acknowledge the technical support of Indian \\ Institute of Finance and IIF Business School. We would such as to thank \\ Prof. Jaurahi Ali (University Utara Malaysia, Malaysia), Prof. Manuel Jose
}

${ }^{1}$ The paper has been accepted and presented at the $7^{\text {th }}$ ISINI International Conference on "Frontiers in Finance and Economics" at Ecole Supérieure de Commerce de Lille, France. The paper was presented in the session Chaired by Prof. Patrice Fontaine, President, AFFI, France on $22^{\text {nd }}$ August 2003 (16:00 - 18:30).

This paper is based on earlier versions of the paper which were presented and published

a. National Conference on "Indian Management Education: Vision 2010" - paper titled "Management Education: Steps for 2010" of PHD Chamber of Commerce and Industry, Delhi, INDIA. Also published in Conference Volume. $21^{\text {st }}$ August 2002 (invited speaker)

b. "Management Education: Steps for 2010", 123 India.com, Bombay, Sep 2002, (invited paper)

c. "Governance Growth Model for Management Education: Steps for 2010", IIF Newsletter IIF Newsletter, Vol XVI No 8 \& 9 (August - September 2002) issue.

d. National Conference on Industry Institute Partnership for National \& Institutional development (under auspices of the AICTE) on "Economic Governance of Educational Institutions", Coauthored with Yamini Agarwal (Delhi School of Economics, India), NCIIP Conference Volume 2003, Sangrur, Panjab, INDIA (6-7th February 2003). (Invited keynote speaker and chair session)

e. National Conference on Brand Building: The New Survival Mantra (under auspices of the AICTE) on "Self Assessment Governance Growth Model for Educational Institutions", Coauthored with Yamini Agarwal (Delhi School of Economics, India), IBMR Conference Book, IPS Academy, IBMR, Indore, INDIA (15-17th February 2003). (Invited Keynote Speaker, Guest of Honour \& Chairperson Valedictory Session)

f. Invited as special chapter for a book on Knowledge Management \& Growth to be authored Prof. D. N. Mithani, University Utara Malaysia, Malaysia.

g. $13^{\text {th }}$ World Congress on Total Quality "Delivering Business Transformations through Quality Approaches" Coauthored with Yamini Agarwal (Delhi School of Economics, India), 14-16 ${ }^{\text {th }}$ February 2003 at Hotel Maurya Maratha Sheraton, Mumbai, INDIA.

* Director \& Professor of Finance, Indian Institute of Finance (Indian Institute of Finance - URL: http://www.iif.edu), Delhi, Chief Editor, Finance India (Finance India - The Quarterly refereed journal of finance of Indian Institute of Finance. URL: http://www.financeindia.org), Delhi.

* Director, IIF Business School (Contact Address: IIF Business School (GGSIPU), 4, Community Center II, Ashok Vihar II, Delhi 110052. INDIA Email: aa@iifbs.edu or aa@iif.edu or jf@vsnl.com, URL: http://www.iifbs.edu), GGS Indraprastha University, Delhi. Honorary Professor of Uzbekistan, Tashkent State University of Economics, Uzbekistan. Adjunct Professor of Finance, Indian Institute of Finance, Delhi. Associate Editor, Finance India, Delhi. Editorial Board Member, Empirical Economic Letters (Empirical Economic Letters - Bi-monthly journal, Bangladesh ), Bangladesh. Editorial Board Member, Journal of Entrepreneurship, France.

**** Lecturer, Indian Institute of Finance, Delhi 
da Rocha Armada (Univ. of Minho, Portugal), Dr. Hiroshi Kawamura (TNC Monitor, Japan) Prof. Kanti Sawrup (IIF) and corporate's for their valuable comments and suggestions. We would also such as to thank the research faculty of the institutions for their support with the understanding of subject and data. The views and reviews presented in the paper are views and opinions of the authors, based on their research and experience and do not depict institutional or countries' views or of the institutions the authors are associated with. All errors and omissions are our own.

\section{Introduction}

A great deal of attention has been paid to global economic issues in the last decade. This has been a natural byproduct of the increasing interdependencies of all national economies and the growth in entrepreneurship and a competitive environment. This has accentuated in recent years due to the emergence of several developing countries as global economic forces, the reorganisation of the production process, change in nature and location of development and finance. One can clearly observe this with the economic growth and self sufficiency attained by India, China and the quick re-emergence from crisis of the ASEAN countries.

The last decade has witnessed varied economic performance worldwide. Looking at Asia, we find that growth rates in India and China have held up well since the mid 1990s, a number of East and Southeast Asian economies were hit hard by the financial crisis, with severe GDP contractions in 1997-98 (see Figure 1). These were Thailand, Indonesia, Korea, Malaysia and the Philippines. A general rebound in growth since 1999-2000 has been observed (see Figure 2; Table I). Though growth has been volatile in comparison with the pre-crisis period followed by weakening in 2001 and strengthening in 2002 in Asia. The recovery as said before has been by a resurgence of exports, extensive inflows from the rest of the world into Asia, emergence of services sector, exchange rate adjustments and increase in government expenditures. 


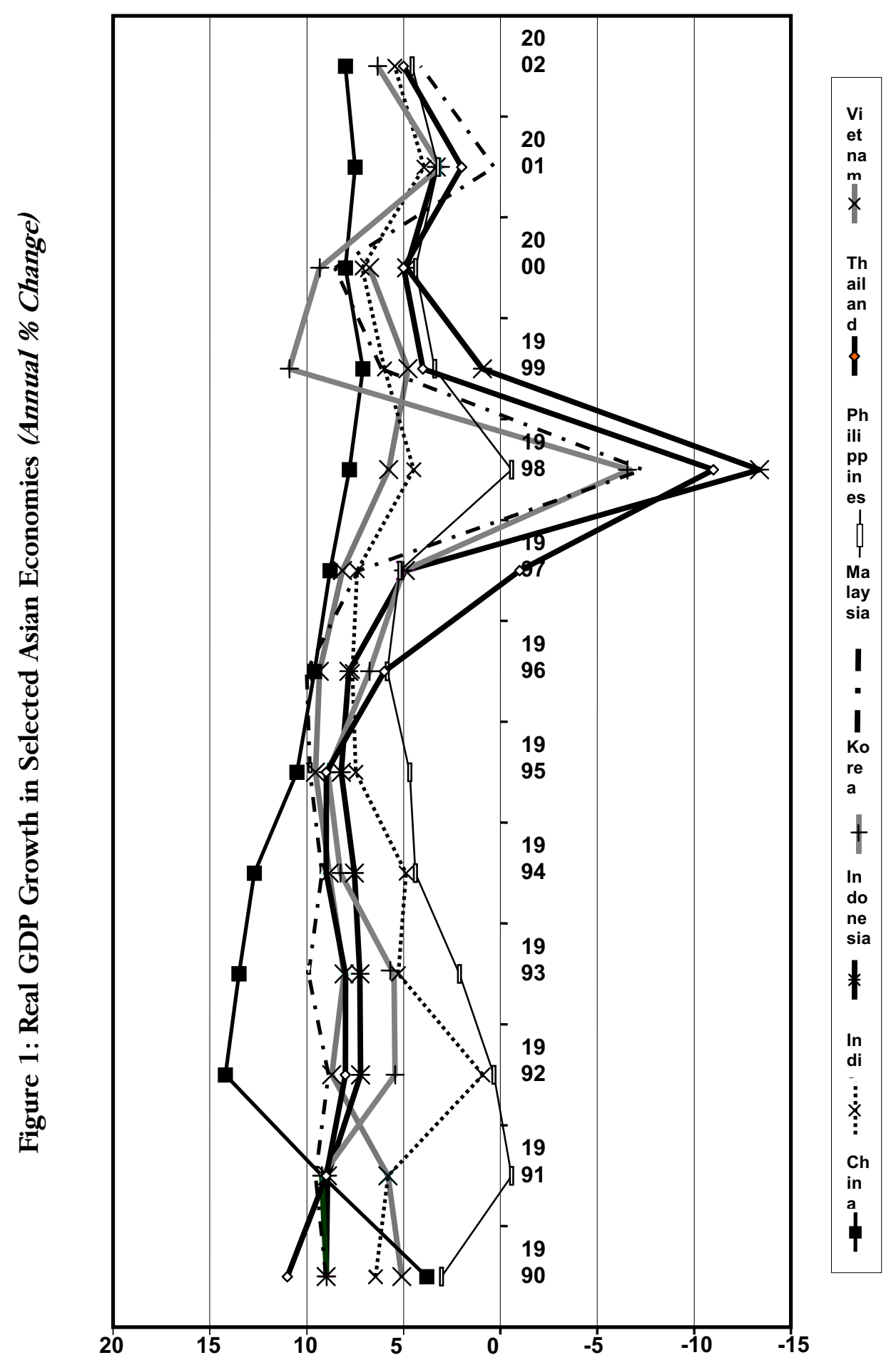


30 The Lahore Journal of Economics, Vol.9, No.1

Table I: The share of demand components in GDP (\% of GDP)

\begin{tabular}{|c|c|c|c|c|c|c|c|c|c|}
\hline COUNTRY & $\begin{array}{c}\text { Govt. } \\
\text { Consumption } \\
\text { (1) }\end{array}$ & $\begin{array}{c}\text { Govt. } \\
\text { Consumption } \\
\text { (2) }\end{array}$ & $\begin{array}{c}\text { Govt. } \\
\text { Consumption } \\
\text { Change } \\
(2-1)\end{array}$ & $\begin{array}{c}\text { Net } \\
\text { exports } \\
\text { (3) }\end{array}$ & $\begin{array}{c}\text { Net } \\
\text { exports } \\
(4)\end{array}$ & $\begin{array}{c}\text { Net } \\
\text { exports } \\
\text { Change } \\
(4-3)\end{array}$ & $\begin{array}{c}\text { Invest. } \\
(5)\end{array}$ & $\begin{array}{c}\text { Invest. } \\
\text { (6) }\end{array}$ & $\begin{array}{c}\text { Invest. } \\
\text { Change } \\
(6-5)\end{array}$ \\
\hline & 1995 & 2001 & & 1995 & 2001 & & 1995 & 2001 & $\begin{array}{l}2001- \\
1995\end{array}$ \\
\hline PRC & 11.4 & 13.2 & 1.8 & 1.7 & 2.2 & 0.5 & 34.7 & 37.3 & 2.6 \\
\hline India & 10.8 & 12.8 & 2.0 & -1.2 & & 1.2 & 24.4 & 21.7 & -2.7 \\
\hline Indonesia & 7.8 & 7.4 & -0.4 & -1.3 & 8.5 & 9.8 & 28.4 & 20.9 & -7.6 \\
\hline Korea & 9.7 & 10.4 & 0.7 & -1.5 & 2.3 & 3.8 & 36.7 & 27.0 & -9.7 \\
\hline Malaysia & 12.4 & 12.6 & 0.2 & -3.9 & 18.4 & 22.3 & 43.6 & 24.9 & -18.7 \\
\hline Philippines & 11.4 & 12.1 & 0.7 & -7.8 & -3.1 & 4.7 & 22.2 & 19.6 & -2.6 \\
\hline Thailand & 9.9 & 11.6 & 1.7 & -6.7 & 6.5 & 13.3 & 41.1 & 23.0 & -18.1 \\
\hline Vietnam & 8.2 & 6.3 & -1.9 & -9.1 & -3.3 & 5.8 & 24.7 & 28.9 & 4.1 \\
\hline
\end{tabular}

Source: International Monetary Fund: IFS 


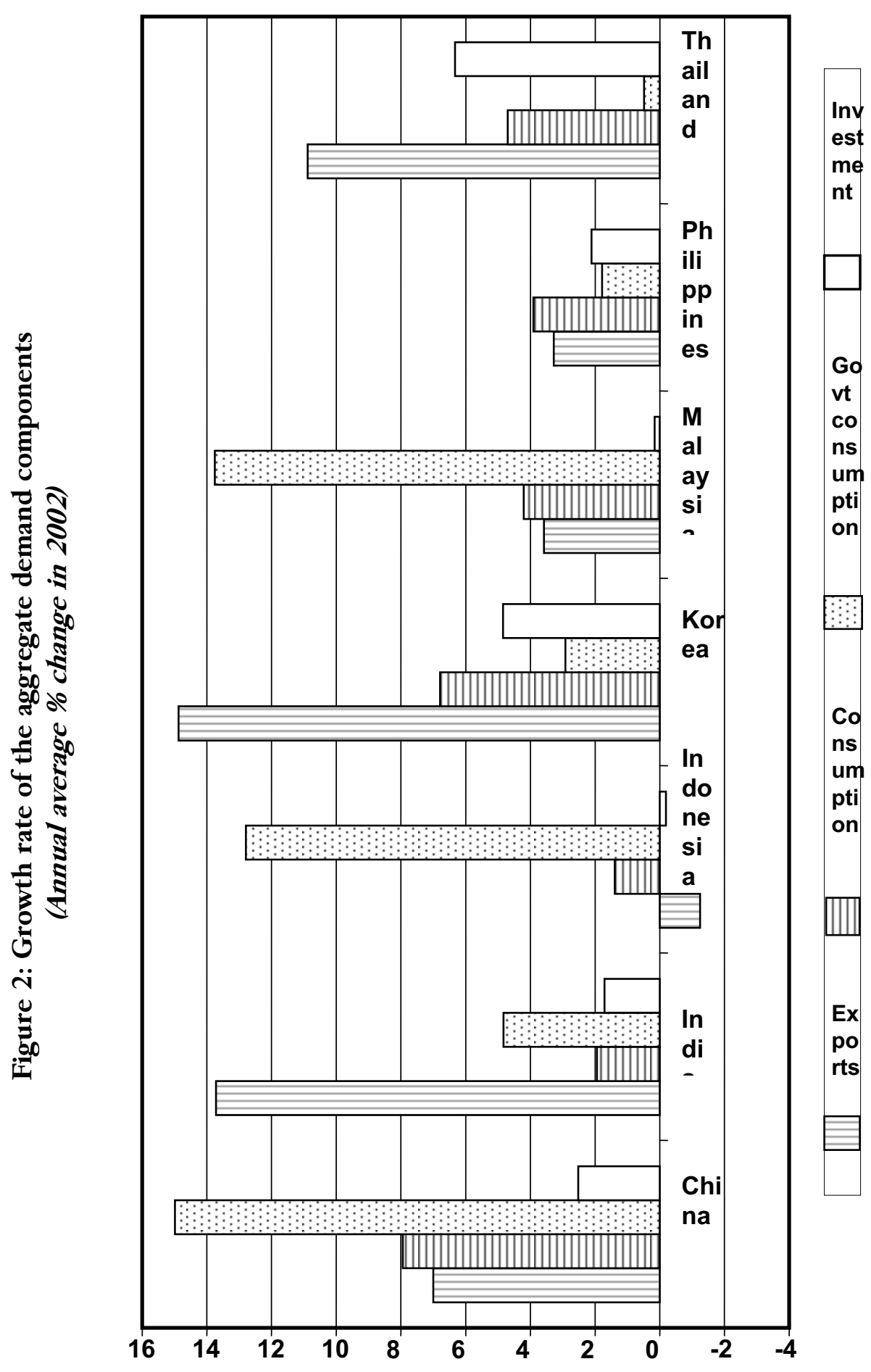


Education, good governance and quality consciousness facilitate growth and development of corporations and society. Proper education and not just literacy need to be provided to the internal and external stakeholders of an organisation to achieve the desired governance and total quality growth factors, which in turn lead to organisational goal fulfillment. Knowledge either imported or home spun has signalled new challenges and improved the quality of life. A serious emphasis has been put forward since the new economic order set up in 1991 to redefine goals, objectives and have an application oriented institutional set up to bring about economic growth, development and nourishment. A huge amount of private equity and initiative has taken place over the last decade to bring about sustained economic development in the absence of an appropriate institutional setup in areas which were opened up in the last decade. This has led effectively to produce competent human capital for national development, since the latter without the former is such as life without oxygen.

Quality in today's globalised Gurukul is termed as adhering to international norms and practices. It is viewed as the responsibility of the government, professional bodies, accrediting agencies, associations and chambers, industry and society at large. Focus of Total Quality has been tuned towards maintenance of the highest standards for thoroughness, innovation, and attention to detail so as to evolve a reputation for reliability and prompt and friendly customer service. Total Quality Management now is the structured system for satisfying internal and external customers and suppliers by integrating the business environment, continuous improvement, and breakthroughs with development, improvement, and maintenance cycles while changing organisational culture. It is such as building a house with perfection. When all elements in TQM are well placed, it would generate a well-built house with a strong, solid, cohesive foundation. (See Figure 3)

One of the multi-layered approaches to bring in quality assurance has been by adopting a phased plan. The four stage phased plan is

1. SWOT Analysis of institutions ${ }^{2}$

2. Self-Study, Assessment and Accreditation of institutions ${ }^{3}$

\footnotetext{
${ }^{2}$ An extensive analysis on the Strengths, Weaknesses, Opportunities and Threats before an educational institution and setup. The understanding of strengths and weaknesses helps formulate capacity-building. This self-assessment approach of an educational institutional setup enables appropriate diagnosis and measures the control over the assessment.

3 The second stage in this is to conduct self-evaluation process, assess or engage an external institution to evaluate the performance or competence of the institution. This is also done through ratings, rankings or accrediting bodies at national and international
} 
3. Remedial measures in the case of week and less privileged institutions $^{4}$

4. Implementation of quality sustenance activities in accredited institutions $^{5}$

Figure 3: Total Quality Management

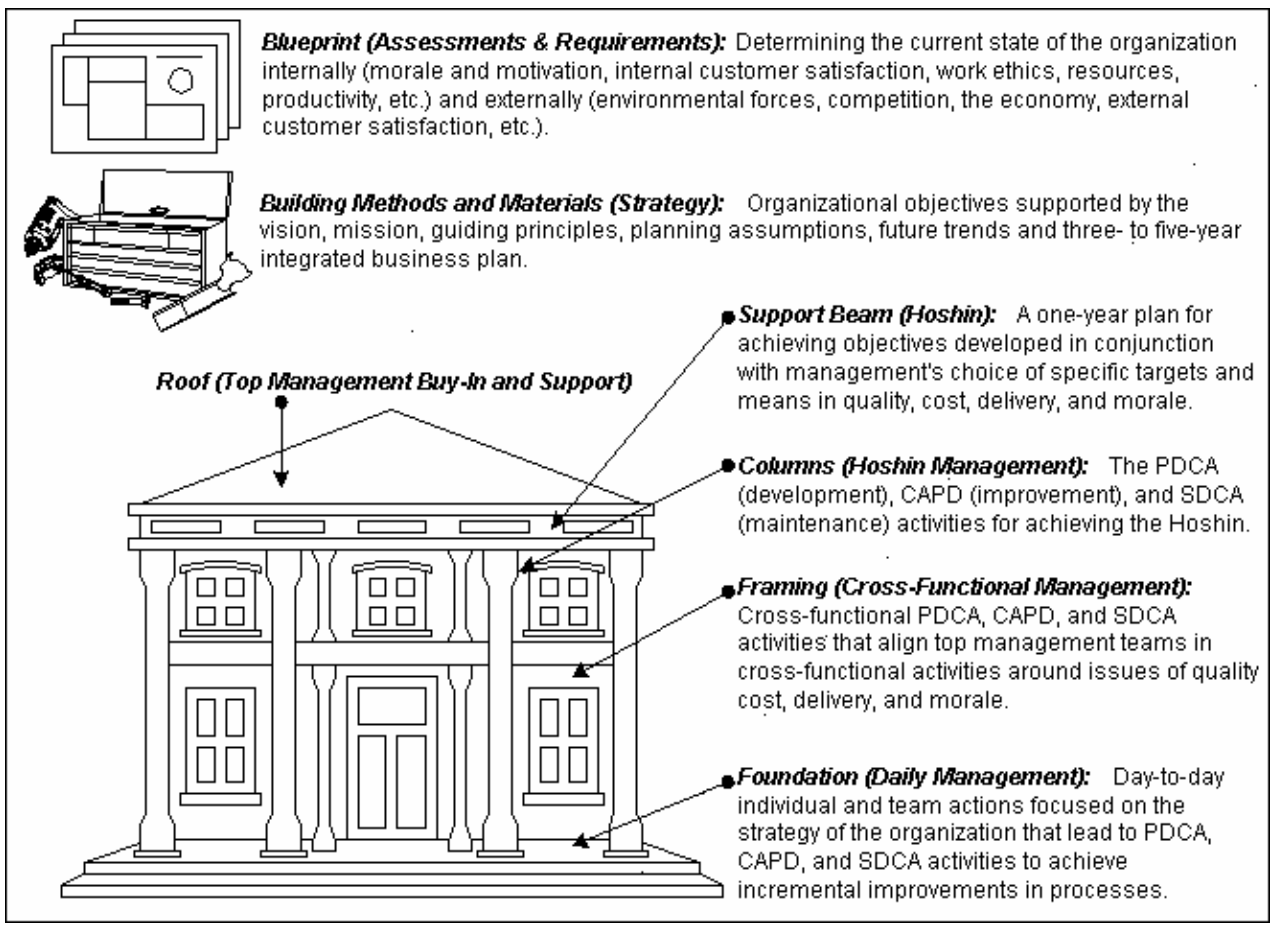

Source: Hoshin Kanri, Integrated Quality Dynamics, Inc.

New global standards of governance are emerging. Customers are demanding better performance on the part of the corporates and their governments. They are increasingly aware of the costs of poor management and corruption. These developments have led to new interest in measuring the performance of corporations, institutions, and governments. This may be

levels. This process enhances the insight on the strengths, weaknesses and opportunities before an institution. It also gives a new sense of direction., promoting inter and intra institutional interactions and directions to the institution under evaluation.

${ }^{4}$ It is for the betterment of any setup, that there is natural, equal and sustained growth. But nature plays its own role. Differentiation is the rule of nature and the survival of the fittest is the game.

${ }^{5}$ This enables the bringing in of quality promotion, develop a network to promote educational enrichment and maintain collaboration for growth and exchange. 
done by international agencies, credit rating organisations or self-assessing models, which use indicators of governance, institutional quality and corporate governance ratings. The model given in the paper highlights and brings forth some of the relevant factors that touch upon some of these sensitive issues, and which many times companies are not willing to disclose or open up. However, it is difficult to hide one's face from the mirror. Hence a self-evaluating and assessing mechanism/model is the need of the hour, which is the purpose in this paper. We have also highlighted the position of the Education Sector along with case study of an institution, which has emerged as a leader using the mode1.

\section{Quality and Governance in the Education Sector}

In India, the emphasis of quality assurance has resulted in an all round concern, as can be seen from the decision of the Ministry of Human Resource Development (MHRD) and AICTE functioning. The MHRD has announced the calendar year 2002 as the "Year of Quality of Higher Education" (Pillai and Ponmudiraj). This is expected to bring forth quality initiatives and the needed stimulus in the government supported educational setup. Some of the questions we need to pose are -

- What policies foster knowledge enrichment?

- What policies enhance a country's learning synergy?

- What policies improve the effectiveness of communication and effective utilisation of resources (finance, infrastructure \& human capital)?

UGC and MHRD have been trying to develop and seek answers to some of these pertinent question. A series of steps have also been initiated. However, growth and qualitative education is not being achieved. The issues relating to faculty, research and quality education constitute the core of an educational process. The competence and dedication of teachers, their constant upgradation, the pedagogy, the level and quality of inputs, performance levels are some of the basic determinants of a good education setup. Hence, there has been a greater emphasis to bring in self-sustained institutions and organisations in the new economic order.

The MHRD, UGC \& the AICTE have done a formidable task since 1993 by approving a large number of institutions in the areas of engineering, management, pharmacy etc. to fill-in the wide gap which existed between demand and supply of technical education in the country. In the process these institutions have also become a target of criticism in some quarters for not maintaining the desired quality of education. Whenever such a formidable task is undertaken there can always be some 
mistakes which may evoke some criticism. In this regard UGC and AICTE should have taken the necessary steps to build up its image through transparency, accountability and by holding seminars so that excessive criticism could have been avoided.

When the Indian economy moved from a controlled regulated economy system in 1991, licensing shifted from Udyog Bhawan (Industry) to education in Indra Gandhi Indoor Stadium(AICTE) and lately also to UGC to attain Deemed University status. All types of people jumped to take advantage of this opportunity i.e. licensing process. AICTE was converted into a licensing authority in the 90 instead of becoming a regulatory authority as was foreseen to be its prime role. Emergence of technical Universities and AICTEs insisting on simultaneous affiliation with some university for technical institutes although thought to cure the ills and maintain quality education, instead brought massive corruption at the University level -which was largely free from the corruption. What we need is to have effective, efficient and a flexibly dynamic diversified system, wellknit into the global framework to transform management/technical education fulfilling societal and national needs.

There has been a phenomenal increase in the number of universities and colleges under the governmental and private educational setup in the country in the last one decade.

\begin{tabular}{llll}
\hline & $\mathbf{1 9 4 9 - 5 1}$ & $\mathbf{1 9 9 6}$ & Current \\
\hline Universities & 28 & 224 & 278 \\
Colleges & 695 & 8613 & 11,000 \\
Student Enrollment & $2.51 \mathrm{akhs}$ & over 70 lakhs & 7.5 million \\
Teacher & 12,000 & 3 lakhs & 3.42 lakhs \\
\hline
\end{tabular}

Note: Data is for the colleges and universities under UGC

Source: Venkatasubramanian K, 2002, Financing of Higher Education, The Hindu, February 19, 2002

Although the statistical growth in number seems to have been a phenomenal growth, the educational infrastructure and institutions do not cater to the growing need of over 10 million people enrolling annually (including those in private institutions). Educational institutions in almost all spheres are required to meet the growing demand. Management has come up as one of the most demanding subjects, which has seen the highest growth after engineering and medicine at the post-graduate level. With this India stands to be the second largest higher educational setup after the US, with a difference of demand for education being domestic. 


\section{Self-Assessment Economic Governance \& Total Quality Growth Model :}

\section{Corporations}

The model for economic governance and total quality self-assesses and induces growth within an organisational setup. It enables one to ascertain the weak points, streamline resource allocation and develop the organisation in totality. This model is a self-assessing model, which enables the management of the company to judge its position based on their own perceptions and positioning in a dynamic ever-changing environment. It can be applied to all different kinds of organisations and need not be restricted to any certain category. In the model, we have identified eight factors to self evaluate and govern. Seven out of these eight are based on surveys and research. The seven basic components which an organisation needs to focus on for economic growth, governance and total quality factor are - Vision, Leadership, Finance, Human Resource, Work Environment (Technical Resources, Equipment \& Infrastructure), Research \& Innovation and Market Acceptability. We have left one of the options as open for the management to choose and determine based on the need and focus of operation. All organisations irrespective of nature of work and structure are influenced by the environment where they need to demonstrate flexibility, dynamism and empathy, while remaining true to the core values.

\section{Vision}

It is vital to give necessary direction to any organisation and its stakeholders. It enables bringing in clarity and focus to the organisational functioning in today's challenging and uncertain environment. $\mathrm{Be}$ it at the national or an organisational level, its importance is well recognised and the vision is formulated mostly at their inception stages.

The vision should have components such as - What the organisation wants to be, not what it is; What are the future products or services concepts, not specific products and services?; What is the future market area, such as global/international?; Should the statement be in line of stakeholders expectations?

The mission should have components such as - how to achieve the vision within a certain time frame?; What and how have the activities to be initiated to achieve the corporate vision?; 
Both the vision and mission statements must fulfill these components Should the statement be in line with stakeholders expectations?; Should the statement be a simple statement?; Is the statement understandable from top management to line workers, including the public, customers, and suppliers (stakeholders)?

\section{Leadership}

The correct direction can only be fulfilled, if the right people to direct it are there. Leaders bring the vision into reality with their dedication and commitment. They may be chairman, directors or heads of departments; they all play a leadership role to bring in solidarity and fulfillment of organisational goals. Leadership needs to be dynamically changing but consistent. It ought to meet the needs and objectives of an organisational goal providing it with necessary factors of growth and development. "Positive or Negative" leaders credibility, thinking and attitude has a direct correlation with institutional positioning in the society.

\section{Finance}

This is one of the most vital components to meet operational and growth needs of any organisation. In India, most organisations follow a conservative style in use of finance and tend not to optimise this scarce resource. Finance energises life. It is "THE" factor, which ensures the existence of an organisation. Be it "for" profit or "not-for" profit organisation, all need it as their life-blood. Right and optimal utilisation of this resource has made Reliance, Infosys, Wipro, GE and others and has been the cause of disappearance of Enron, Arthur Anderson, Home trade and others.

\section{Human Resource (Management \& Labour/General Staff)}

It is important that an organisation invests in human capital. The two components - management and labour/general staff form the basic part of these. They over time yield rich returns in terms of brand equity, market acceptability and laying down strong foundations. Continuous Training is a vital component for development and growth of this resource. It keeps one updated with what is happening around the globe in their respective areas. Enrichment of this resource pays in the long run for all organisations. The smooth functioning of any organisation is determined by satisfied and motivated faculty and administrative human resources it posseses. In an increasingly diversified competitive inter- 
dependent institution and corporate world there is a need for educators with leadership in executive roles.

\section{Work Environment (Technical Resource, Equipment \& Infrastructure)}

To lay a strong foundation for the stakeholders of an organisation it is essential for the management to provide a proper healthy work atmosphere. Technical resources and facilities such as the latest equipment, computer based networks and requisite physical infrastructure provide the base for productivity. Though these may not pay an institution in its development immediately, but do act as a multiplying factor for growth in the long run. Also an institution must adhere to strict norms, standards and evaluation system and upgrade its resources from time to time to bring in good corporate governance. This not only enriches the organisation, where the human resources enriched would perform, but also develop an institution in totality.

\section{Research \& Innovation}

Research has been the stepping-stone for organisations of the next generation. Hundreds of companies have innovated and researched products; services and models, which fill in gaps and accelerate growth. Innovation and Research act as catalysts to achieve growth and development in an organisation. Take any top company today, they have used these in some way or the other.

\section{Market Acceptability (Customers, Shareholders, Industry \& Government)}

This is one factor which is given the most relevance by almost all institutions globally. All resources and facilities are for the service of this Most Important Person - MIP (the customer). The customer is the best ambassador of an institution. If the service provided to the customer is in tune with the needs and demands, then the acceptability of the institutions is promising. Industry and Government play a vital role in merging and facilitating customer orientation and growth of the organisation. As Dhirubhai Ambani said "Government is the most important environment of the business". Shareholders act as a major contributor in understanding the market sentiments and acceptability of a company. 


\section{Open Option}

In the model, we have left one of the options as open. This is to facilitate any factor, which an institution or its functionaries think as a relevant variable to be included in the model. This can take a position such as International Reach, Legal Environment, Global Competition, Market Competition, Government Restrictions or any other.

To make the model functional, one needs to sketch out straight lines joining the points on various spheres encircling the corporation (see Figure7). Each sphere shows a higher level of achievement and satisfaction. Each level has been numbered from 1 to 7 , showing the various degrees of achievement and satisfaction. These points link each factor and form a polygon. The uniformity and wideness of the polygon is the desired targeted (see Figure 4, 5 and 6). The larger and the more uniform the polygon, shows that governance is uniform and growth oriented. This also enables an institution to judge its strengths and weakness, wherever the company is on a lower scale. The analysis can be perception or statistical based, depending on the institutional analysis, scale and accuracy the management would such as to bring forth. 
Fig. 4: Minimized

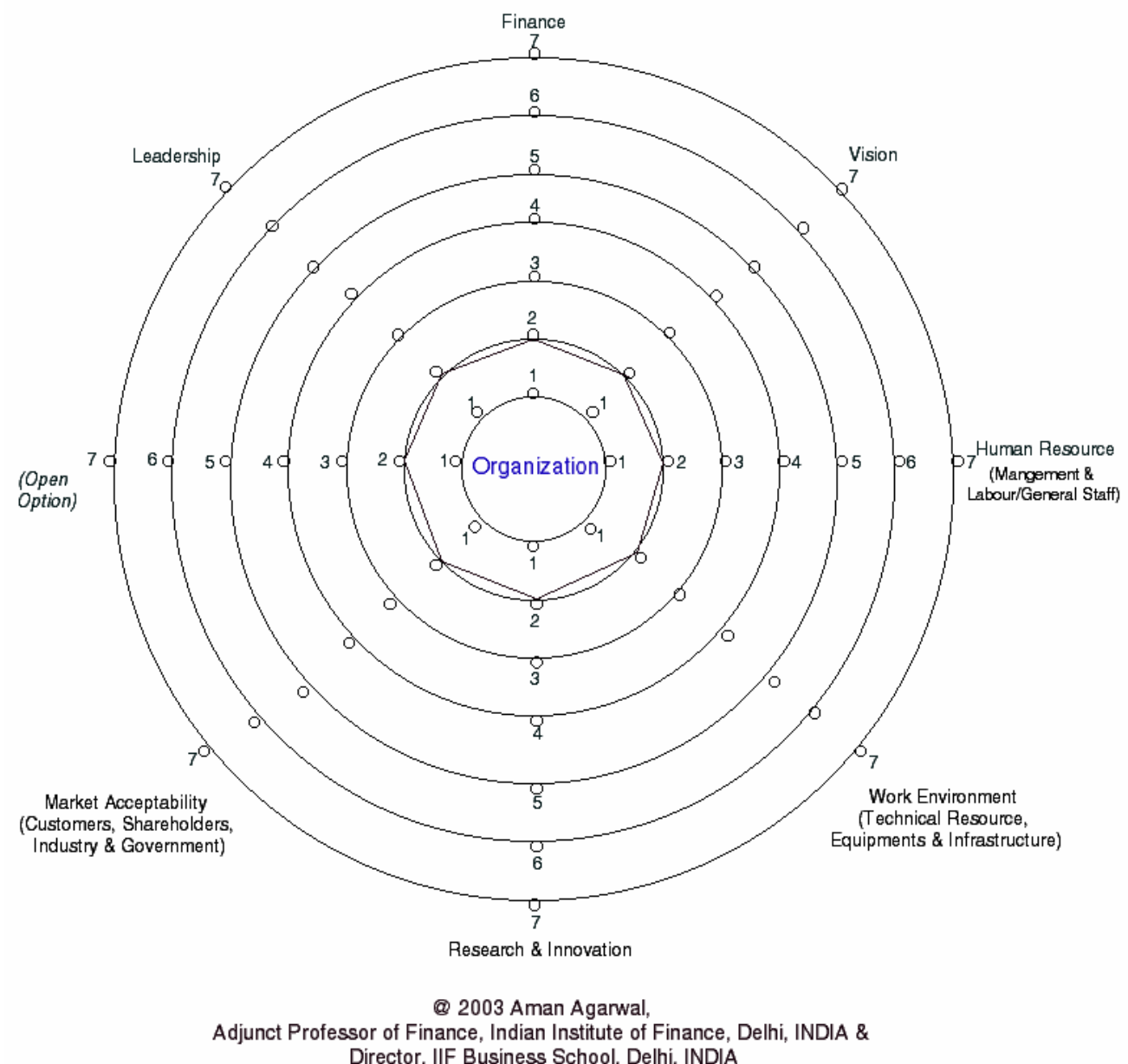
Director, IIF Business School, Delhi, INDIA 
Fig. 5: Normal Scenario

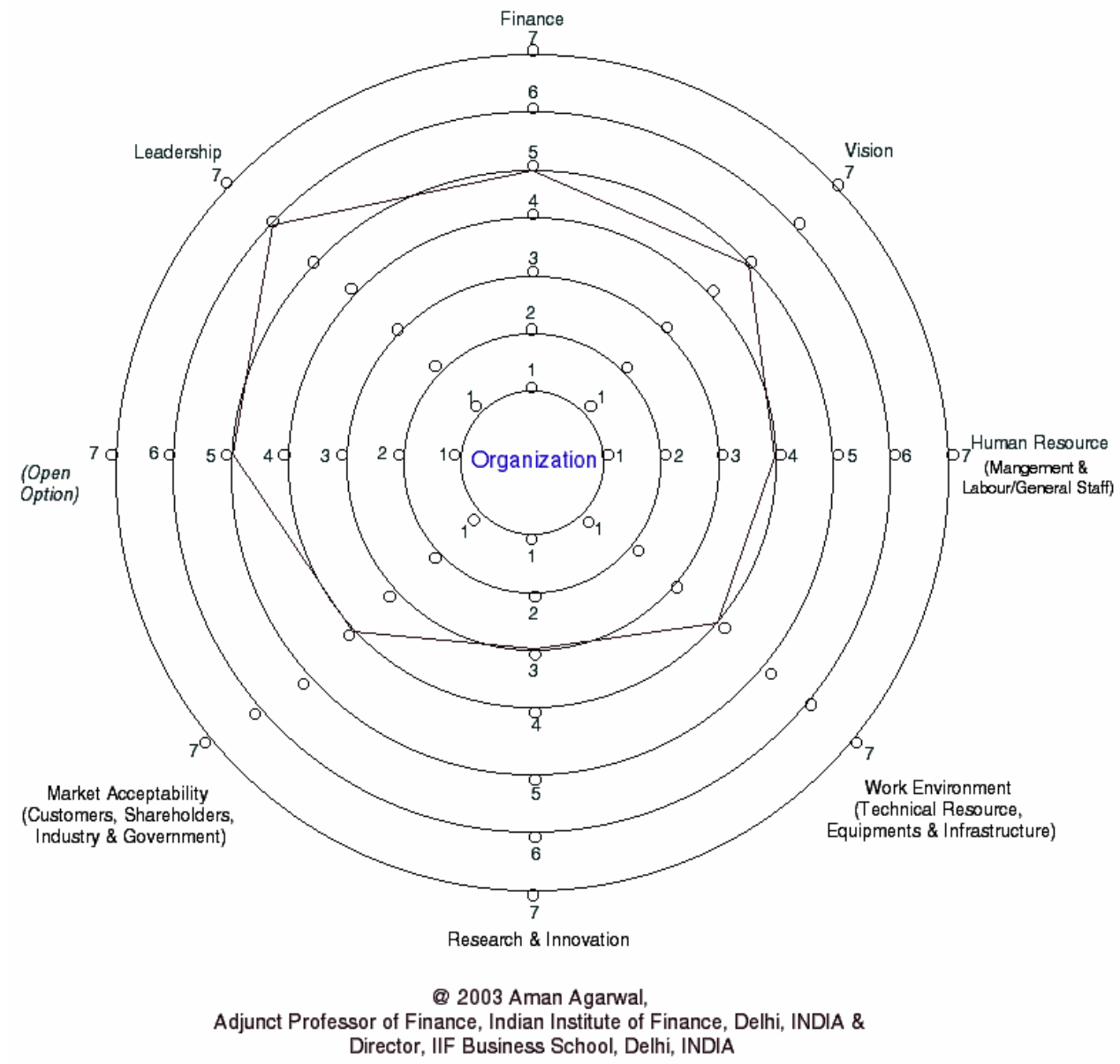


Fig. 6: Optimized (Desired)

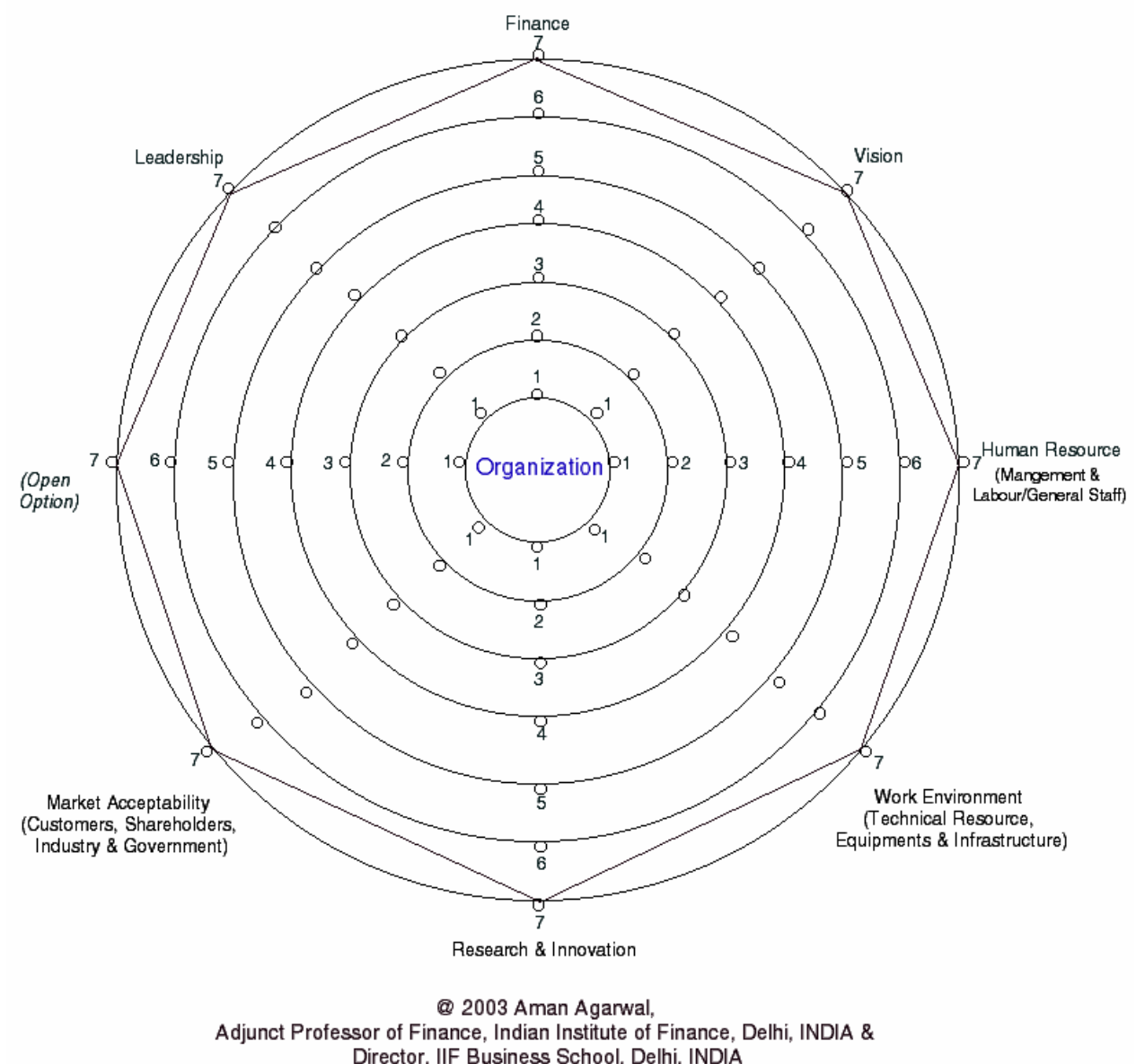


Figure 7: Economic Governance \& Total Quality Growth Model

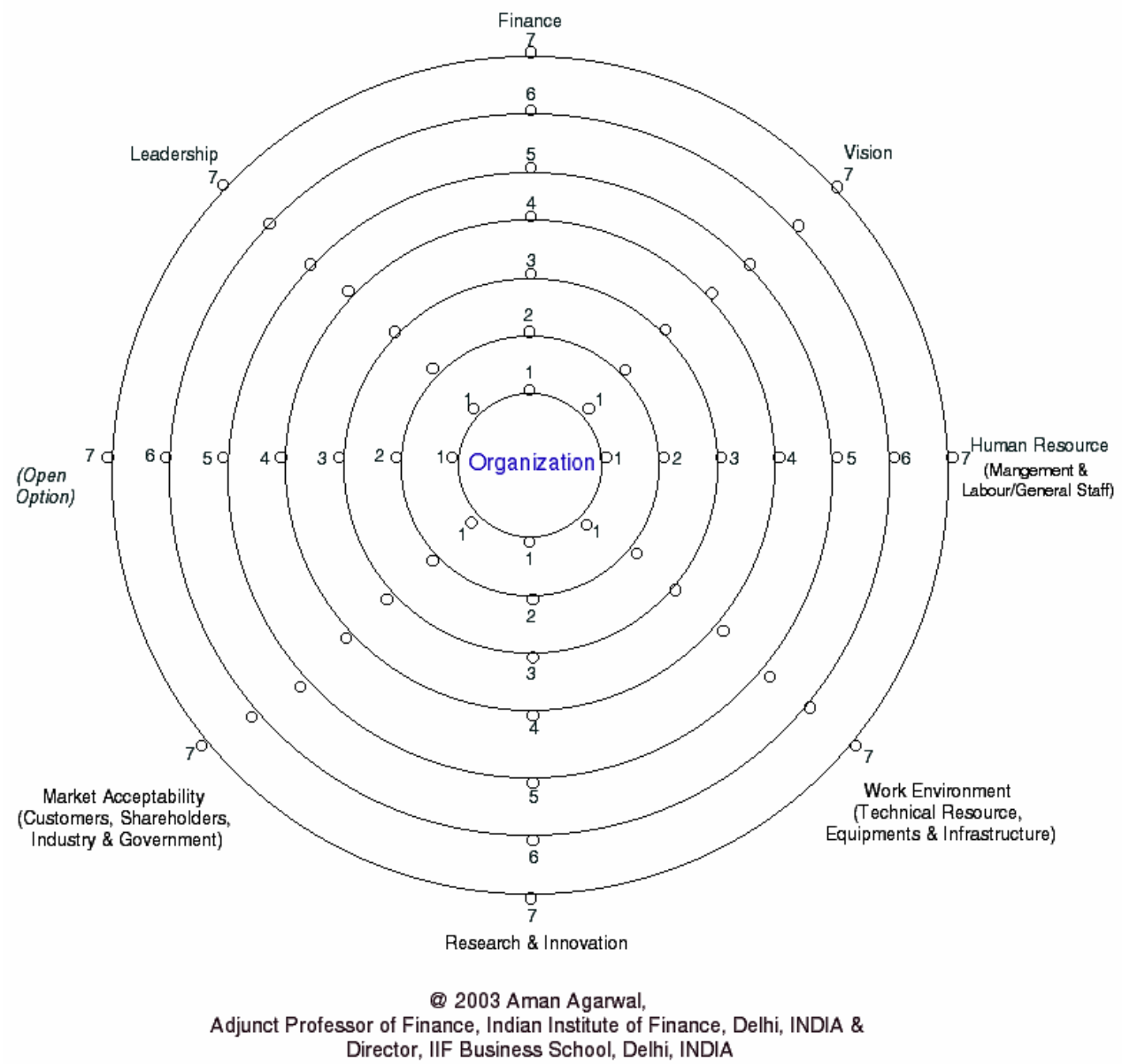




\section{Educational Institutions}

This model for economic governance and total quality empowers an educational institution to self-assess and induce growth within its system. This model is a self assessing model, which enables an institution judge its position based on its own perceptions and position in the society. This also takes into account the environmental factors surrounding an institution. If need be, it can be replicated and used for each functional head in an institution. As in the above case seven out of eight factors/components are pre-determined. These are - Vision, Leadership, Finance, Human Resource, Academic Facilities, Academic Structure and Market Acceptability. One of the options is left open for an educational institution to choose and determine based on their need and focus of operation. The mantra for today's institutional environment is to demonstrate flexibility, dynamism and empathy, while remaining true to the core value's of an institution.

\section{Vision}

It is vital to give necessary direction to any organisation and its stakeholders. It enables the bringing in of clarity and focus to the organisational functioning in today's challenging and uncertain environment. Be it at the national or organisational level, its importance is well recognised and the vision is formulated mostly at their inception stages.

\section{Leadership}

The correct direction can only be fulfilled if the right people to direct it are there. Leaders bring the vision into reality. They may be chairman, directors or heads of departments; all play a leadership role to bring in solidarity and fulfillment of organisational goals. Leadership needs to be dynamically changing but consistent. It ought to meet the needs and objective of an organisational goal providing it with necessary factors of growth and development. "Positive or Negative" leaders credibility, thinking and attitude has a direct correlation with institutional positioning in the society.

\section{Finance}

It is a vital component to meet operational and growth needs of any organisation. Although not much is referred to and made use of by educational institutions. The finances which most educational institutions (in particular management schools) depend upon as a source are the fee of programmes offered and grants from government or 
educational foundations. However, there are various different sources at the disposal of an educational institution. Some of the prominent ones are providing consultancy, conducting MDPs, having an Industry link for R\&D, Alumni and organising events (academic and social). These are possible with the rich resource of human capital and facilities at the disposal of the educational institution.

\section{Human Resource (Faculty \& Administration)}

It is important that an institution invests in human capital. The two components- faculty and administration form the basic part of these. Over time they yield rich returns in terms of brand equity, market acceptability and laying down strong foundations. Research is a vital component for development and growth of faculty. It keeps one updated with what is happening around the globe in their respective fields. Today classroom teaching has to be based on the domestic and international scenario in every subject. The approach has to be a case study and research based approach, with examples, presentations, projects, video presentations, teleconferencing and group/individual involvement.

The smooth functioning of any organisation is determined by satisfied and motivated faculty and administrative human resources it possesses. In an increasingly diversified competitive inter-dependent institution and corporate world there is a need for educators with leadership in executive roles.

\section{Academic Facilities (Library, Computer \& Infrastructure)}

This factor is an essential component for laying a strong foundation for the stakeholders of an educational institution - students, faculty, staff and others. Academic facilities such as the library, computer network and requisite infrastructure provide the foundation for growth and enriching the society with rich human resources. Though these may not pay an institution in its development immediately, they do act as a multiplying factor for growth in the long run.

\section{Academic Structure (Upgrade, Standards \& Evaluation)}

An institution must adhere to strict norms, standards of education, evaluation system and upgrade its programmes and resources from time to time. This not only enriches the society, where the human resource enriched would contribute, but also develop an institution in totality. 


\section{Market Acceptability (Student, Faculty \& Industry)}

This is one factor which is given the most relevance by almost all management institutions globally. All the institutional resources and facilities are for the development of the most important person - MIP (the student) as the student today is the tomorrow of a nation and a progressive society. The student is the ambassador of an institution. If the enrichment provided to the student is in tune with industry needs and demands, then the development of the nation and the educational institutions are promising. The faculty plays a vital role in merging the two components. In the long run the faculty itself becomes a major consistent player for market acceptability, with the research work and knowledge they impart.

\section{Open Option}

In the model, we have left one of the options as open. This is to facilitate any factor which an institution or its functionaries think as a relevant variable to be included in the model. This can take a position such as International Acceptability/Reach, Legal Environment, Global Competition, Market Competition, Government Restrictions or any other.

To make this model function one needs to sketch straight lines joining the points on various spheres encircling the educational institutions (see Figure 11). Each sphere shows a higher level of achievement and satisfaction level. Each level has been numbered from 1 to 7 , showing the various degrees of achievement and satisfaction. These points link each factor and form a polygon. The uniformity and wideness of the polygon is the desired targeted (see Figure 8, 9 and 10). The larger and the more uniform the polygon, shows that the governance is uniform and growth oriented. This also enables an institution to judge its strengths and weaknesses, wherever the institutions is on a lower scale. The analysis can be perception or statistical based, depending on the institutional analysis scale and accuracy they would such as to bring forth. 
Fig. 8: Minimized

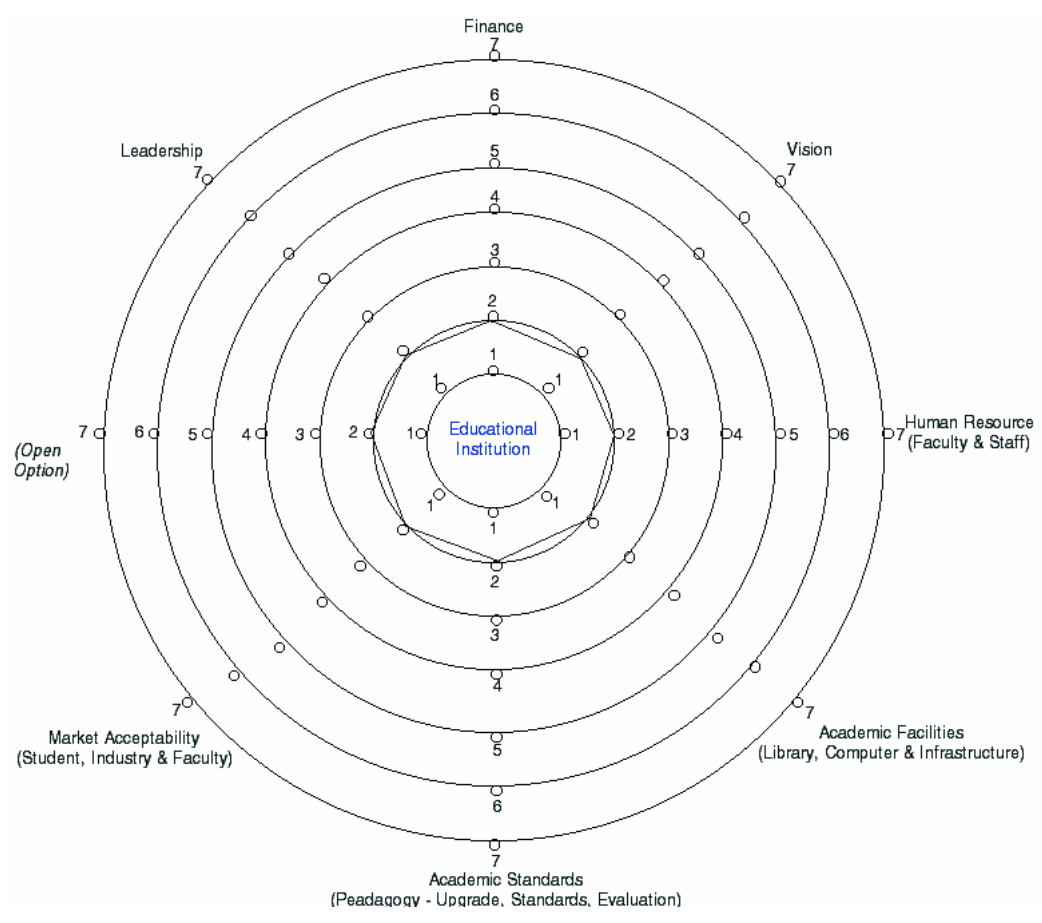

Fig. 9: Normal Scenario

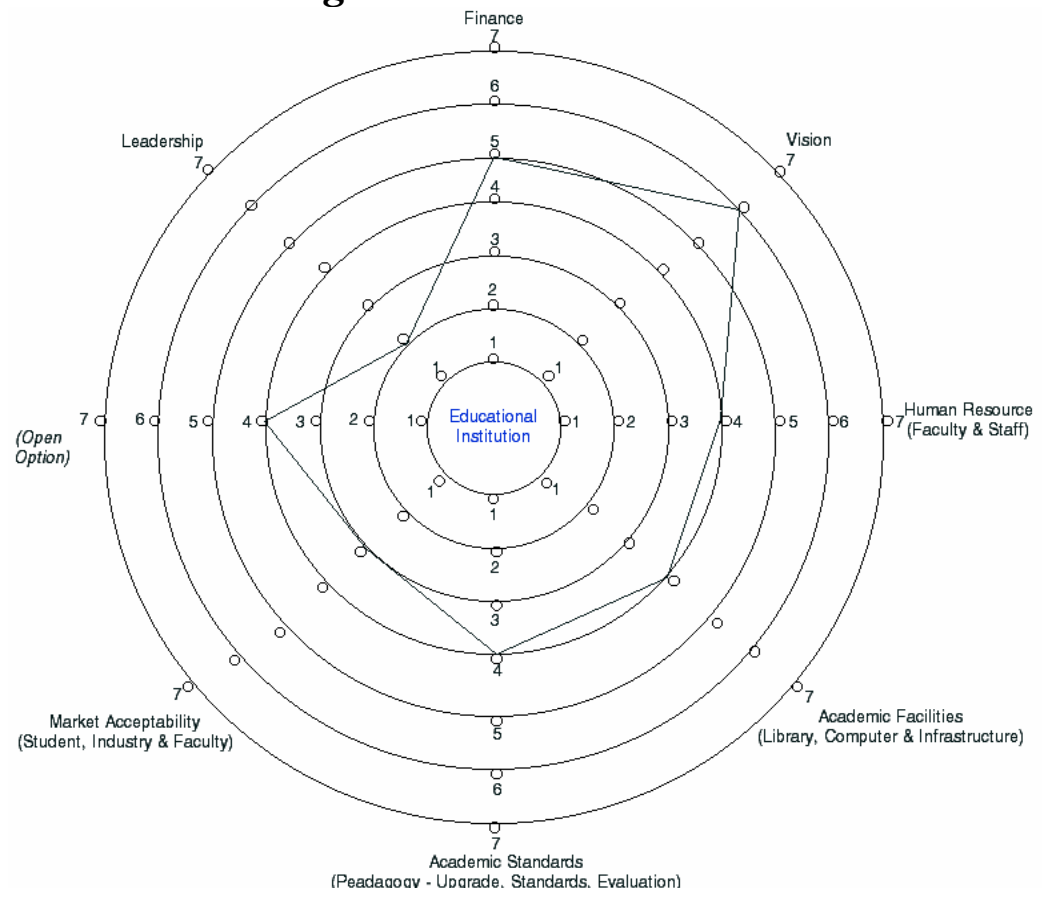


Fig. 10: Optimized (Desired)

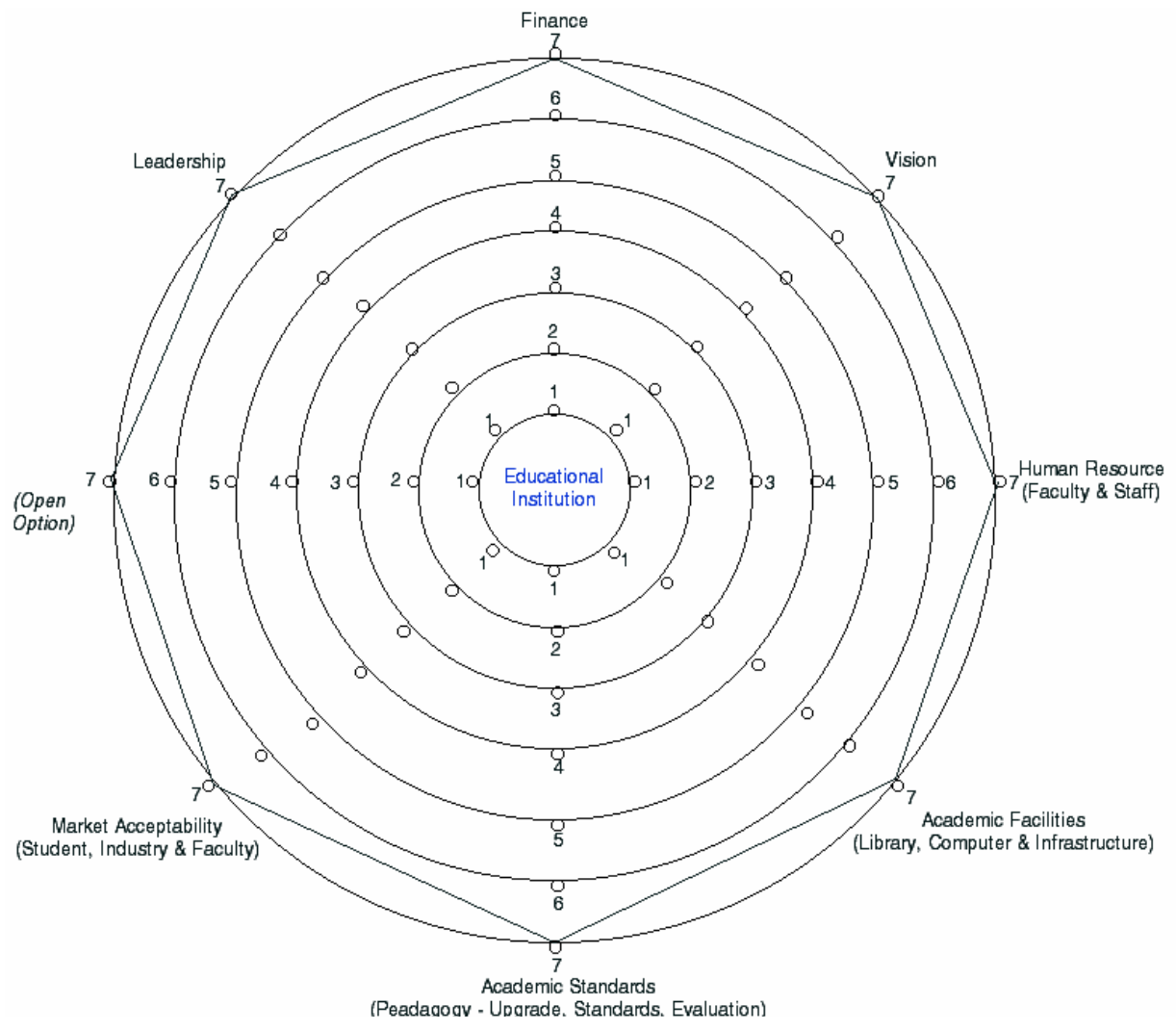


Figure 11: Economic Governance \& Total Quality Growth Model for Educational Institutions

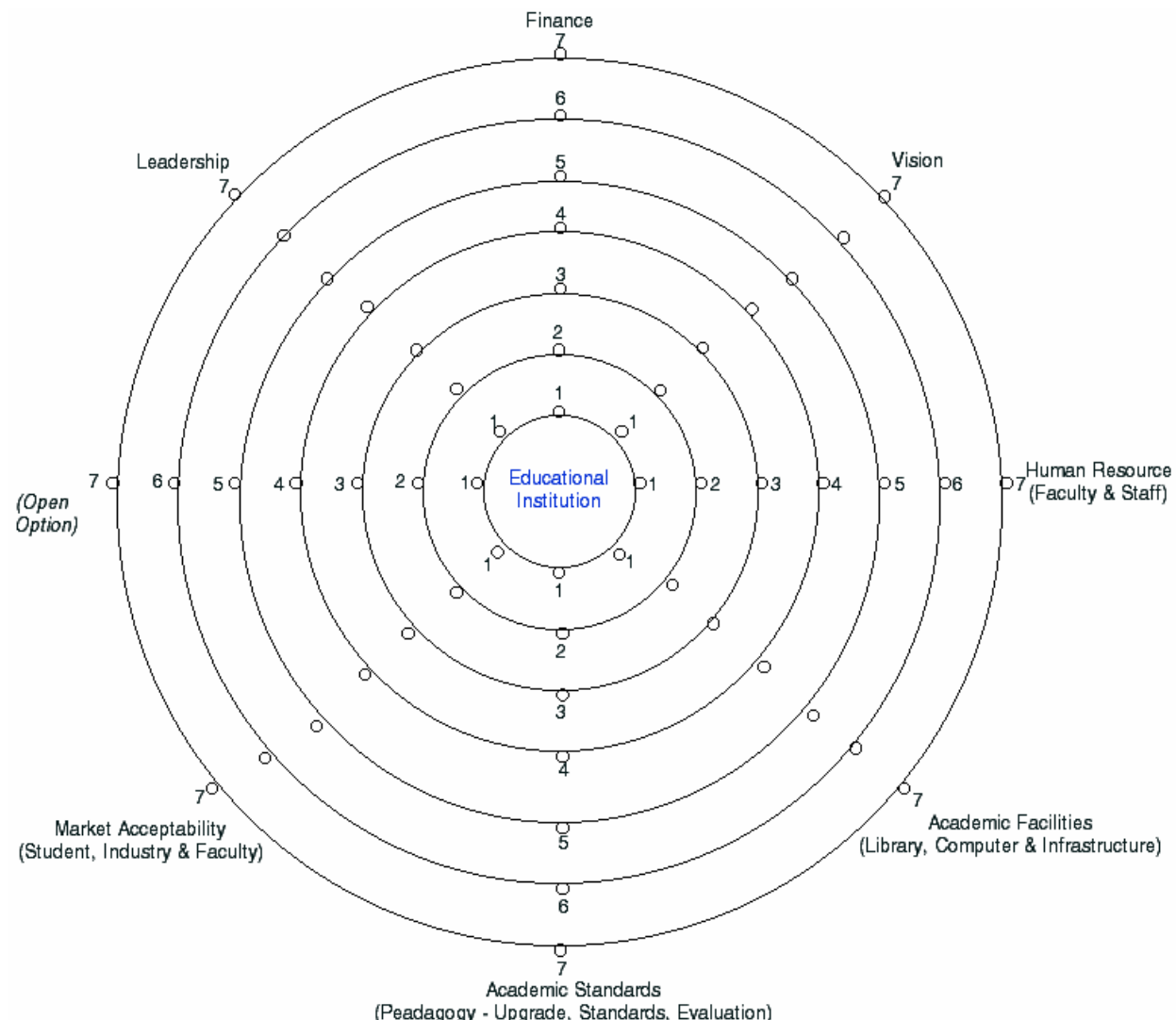


Figure 12: Case I : Governmental Setup (In general, based on value perceptions and survey)

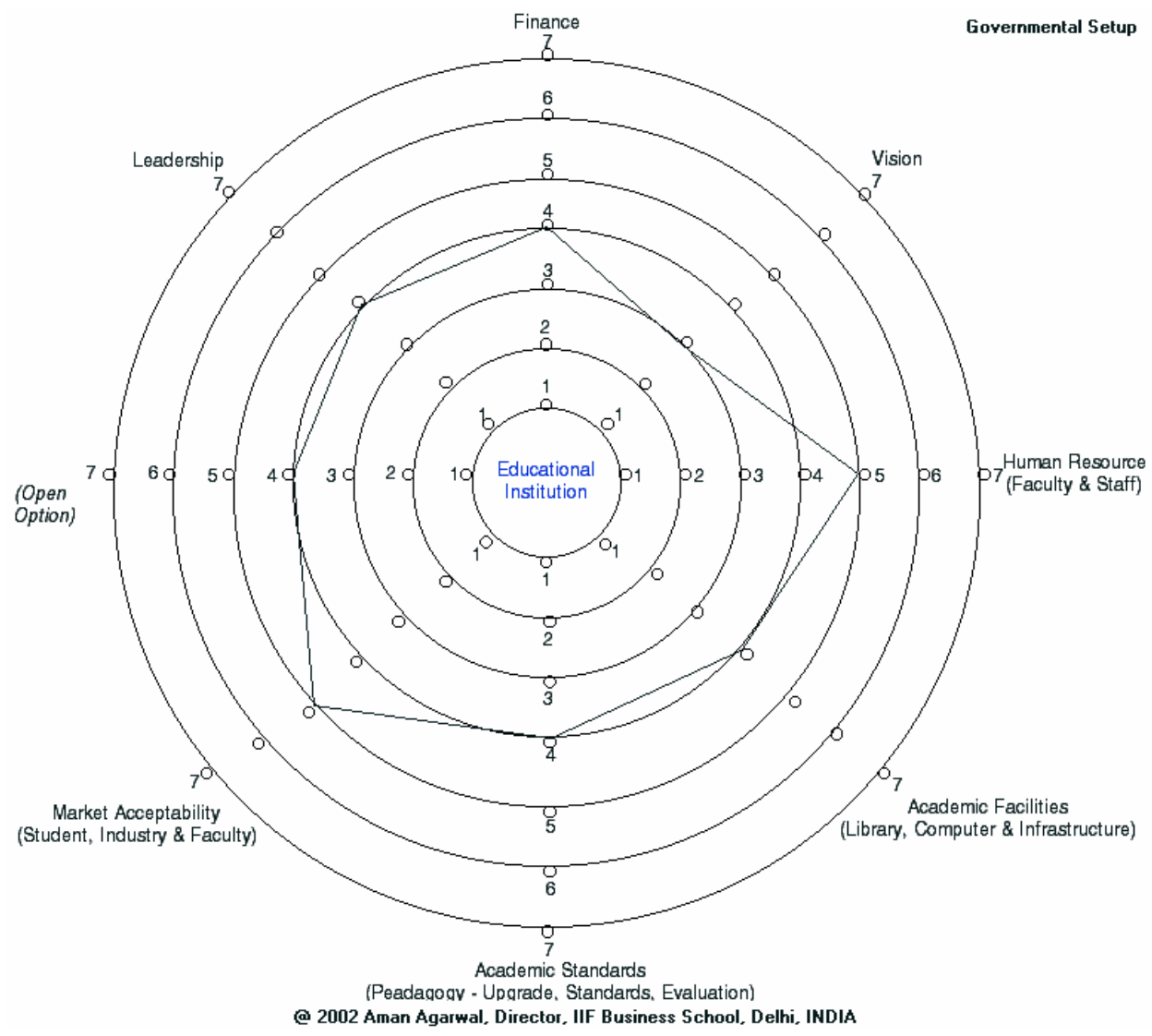


Figure 13: Case II : Private Setup (In general, based on value perceptions and survey)

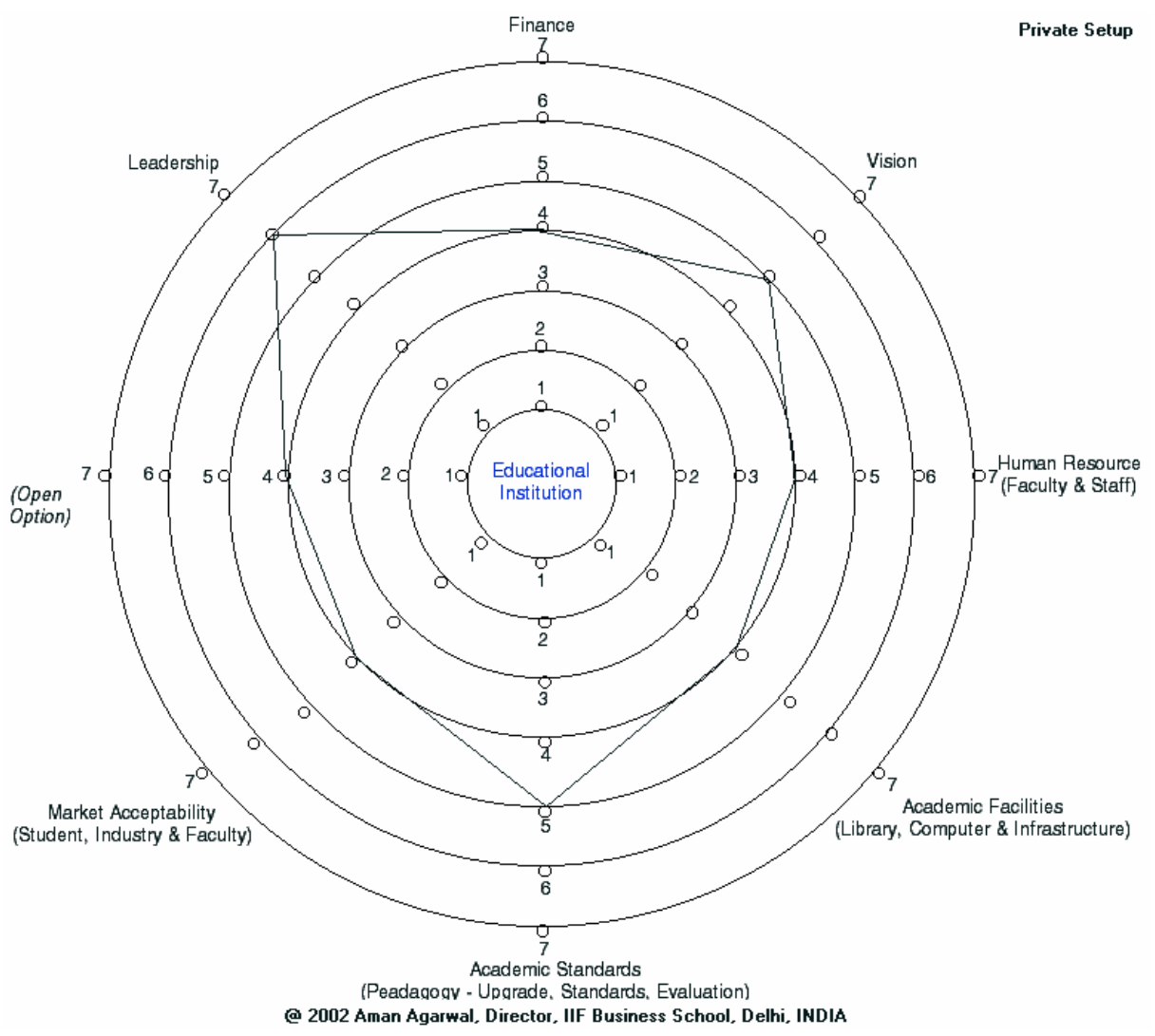

Awareness of self in co-existence with others is vital for organisational success in developing maturity in bringing governance. Institutions need to introduce new business management paradigms. There is also the need to bring in "Unity in diversity" by strengthening our institutions through synergy of the components mentioned in the Governance and Total Quality Model for Growth. One thing which we ought to do as today's mantra for a better tomorrow is to practise what we preach. It is easy to formulate, devise good models and mechanisms, but the implementation of them successfully is even more important. The idea floated by Microsoft recently to have an Implementation Committee to see that implementation of the decisions taken is done is a positive step towards the same. However, the important thing is the implementation and the formulation of the committee. So to begin with this would serve sufficiently for bringing in effective governance in the system. The current 
organisational structure also lacks focus and accountability given the democratic structure organisations in the country. The frauds taking place internationally are substantial evidence of it. With a growing population the need and demand for good governance and total quality systems and organisations is humongous. Even in education, with the current or even three times the current institutional setup of the nation we would be unable to meet the needs of growing India. What we however need are effective and qualitative setups and environments. Though market theorists would agree that the market driven mechanism is an auto adjuster for the same. Unfortunately, with the kind of demand in nations such as India, the cost of market selection for the fittest is very high and counter productive at times.

If we look at the education sector again, Indian education, faculty and students are well appraised and respected for their hard work and knowledge globally. In many of our discussions with our colleagues and friends in universities in America, Japan and Europe, they not only have high regard and respect for Indian education, but also say if a department (in fields such as Mathematics, Finance, Engineering and some areas in Sciences) do not have an Indian faculty, then it is not considered as a well equipped department. This very well brings forth the respect the ambassadors of the Indian education system have created.

Look at some of the famous universities (to mention a few from amongst a larger number) such as University of Cambridge ${ }^{6}$ (UK), University of Oxford $^{7}$ (UK), Harvard University ${ }^{8}$ (USA), Columbia University ${ }^{9}$ (USA), Princeton University ${ }^{10}$ (USA), Yale University ${ }^{11}$ (USA), Stanford University ${ }^{12}$ (USA), Tokyo University ${ }^{13}$ (Japan), London School of Economics ${ }^{14}$, Peking

\footnotetext{
${ }^{6}$ Founded in 1209 . Is ranked $11^{\text {th }}$ with 16 Nobel prize winners. Has the biggest press and one of the most active research centers on contemporary China.

${ }^{7}$ Founded in 1167 . Ranked 1st for numbers of Nobel prize winners. Issac Newton was from this university.

${ }^{8}$ Founded in 1754 . Ranked $2^{\text {nd }}$ with 38 Nobel prize winners. HU had set up the research center in East Asia as far back as 1950.

${ }^{9}$ Founded in 1754 , is ranked $3^{\text {rd }}$ in terms of number of Nobel prize winners.

${ }^{10}$ Founded in 1746 , is ranked $4^{\text {th }}$ in terms of number of Nobel prize winners. Einstein contributed 20 years of his research at Princeton.

${ }^{11}$ Founded in 1701 , is the $3^{\text {rd }}$ oldest university in the US.

${ }^{12}$ Founded in 1891 , is ranked $12^{\text {th }}$ in terms of Noble prize winners. The Silicon Valley is considered to have had its birth in this university through the industrial zone.

${ }^{13}$ Founded in 1877 , is Japan's $1^{\text {st }}$ state founded university and ranked number 1 in terms of academic resources, intake and academic physical infrastructure, based in the heart of the capital city.
} 
University $^{15}$ (China), Australian National University ${ }^{16}$ (Australia), Melbourne University $^{17}$ (Australia), Tohoku University ${ }^{18}$ (Japan), Allahabad University (India), Delhi University ${ }^{19}$ (India), Banaras Hindu University (India), Aligarh Muslim University (India), IITs (India), IISc Bangalore (India), IIMs (India) and the youngest of them - Indian Institute of Finance ${ }^{20}$ (India) are known for their contributions to society, research, academia and setting forth norms of academic environments for institutions internationally. Faculty, which is the most vital ingredient of the academic resource for educational institutions, has been given the most importance while ranking and determining the strengths of an educational institution. Research is the other component, which is used as a determinant of the level an educational institution is rated internationally for the value it holds and the service to the society it can offer. The age and orientation of most of these have contributed to physical structural development. But over the years a few of them have lost their intrinsic worth, the market value and the prestige they enjoyed in earlier years due to poor governance.

As for research being done and disseminated from India, to quote an example, Indian Institute of Finance brings out policy oriented as well as theoretical research in Finance. It is seriously engaged in generating new knowledge and disseminating knowledge. The process of disseminating knowledge is done through teaching and by bringing new publications as well as through its quarterly prestigious 400 page journal Finance India ${ }^{21}$. IIF also holds public lectures, seminars, and think tank meetings. The

\footnotetext{
${ }^{14}$ Founded in 1895, 13 Nobel Prize winners in economics, literature and peace have been either LSE staff or alumni. Is ranked No. 1 for economics and political science worldwide.

${ }^{15}$ Founded in 1889 , is the first state owned comprehensive university with the largest number of professors and research scholars and key laboratories in China.

${ }^{16}$ Founded in 1946, is Australia's $1^{\text {st }}$ research oriented university. In 1960, it was merged with Canberra University College.

${ }^{17}$ Founded in 1853, is amongst the most famous university in teaching from Australia.

${ }^{18}$ Founded in 1907, is the $1^{\text {st }}$ imperial university to have introduced coeducation in the Japanese educational system, opened for foreign students in 1911.

19 Founded in 1921, is the largest university in India for enrollment of over 300,000 students intake yearly. Offers all possible courses through 80 colleges and other departments of the university. Has one of the richest faculty resources.

20 Founded in 1987, is THE best business school in Finance in India, rated $40^{\text {th }}$ Worldwide by American Statistical Association known for the research contributions and faculty resource. The refereed journal - Finance India is rated $3^{\text {rd }}$ Worldwide by ASA and is referred to as the Bible of Finance. The institution has over 5 Nobel prize winners associated with it, apart from over 200 experts in finance known for their contribution to the literature.

21 The quarterly journal of finance of Indian Institute of Finance. URL: http://www.financeindia.org
} 
journal has been ranked 3rd among 79 finance institutions and also among 148 institutions (of finance, macro economics and labour \& general labour micro-economics) by B\&E Datalinks of American Statistical Association based on ratings for providing financial information and a database. Some of the other institutions/journals rated are Quantitative Finance Journal, NBER, CSRP, Journal of Finance, FRB at St. Louis, FRB at Chicago, EDIRC, Journal of Applied Economics, JP Morgan, US Treasury, Bank of Canada and others. FI has attained a position of a refereed international journal. It is indexed and abstracted by over 13 institutions worldwide. It has some of the most prominent experts from around the world including Nobel Laureates on its editorial board and referees.

\section{Case Study: Indian Institute of Finance}

IIF, setup in 1987, as an autonomous non-profit educational research based institution. IIF in a short span of 15 years has been able to attain a formidable position and place itself on the world map. Some highlights on the achievements of IIF, since 1987 are:

1. Pioneered Business Finance Education in India

2. Bestowed with Internationally recognised experts and celebrated authors in Finance and Management such as Prof. J. D. Agarwal, Prof. A. L. Nagar, Prof. Kanti Sawrup, Prof. M. C. Kapoor, Prof. N. R. Chatterjee, Prof. Manju Agarwal, Prof. Ramanujan, Prof. R. K. Agarwal, Prof. Aman Agarwal and others. Most of these and other Professors are father figures in their fields in India and have theorems and models by their names.

3. Nobel Laureates associated with Finance India and Research activities of the institute - Prof. Franco Modigliani, Prof. Merton H. Miller $^{22}$, Prof. Robert C. Merton, Prof. Robert A. Mundell, Prof. Douglass C. North and others.

4. Over 200 experts in Finance, Accounting and Economics associated worldwide.

5. Implementation of the policies suggested by IIF by various organisations and GOI such as

a. Budget Time Change (1st time in India's history since independence)

\footnotetext{
${ }^{22}$ Deceased 2 years back.
} 
b. Capital Flight issue, which was debated and discussed in Parliament, hence the formation of FEMA and Money laundering bill.

c. Kargil Tax not laid on the citizens of India, immediately after the war.

d. Tax Investment \& Reform schemes observed in last one decade implemented based on the study and book published in 1989.

e. And various others.

Fig. 14: Indian Institute of Finance 1987 (at Inception)

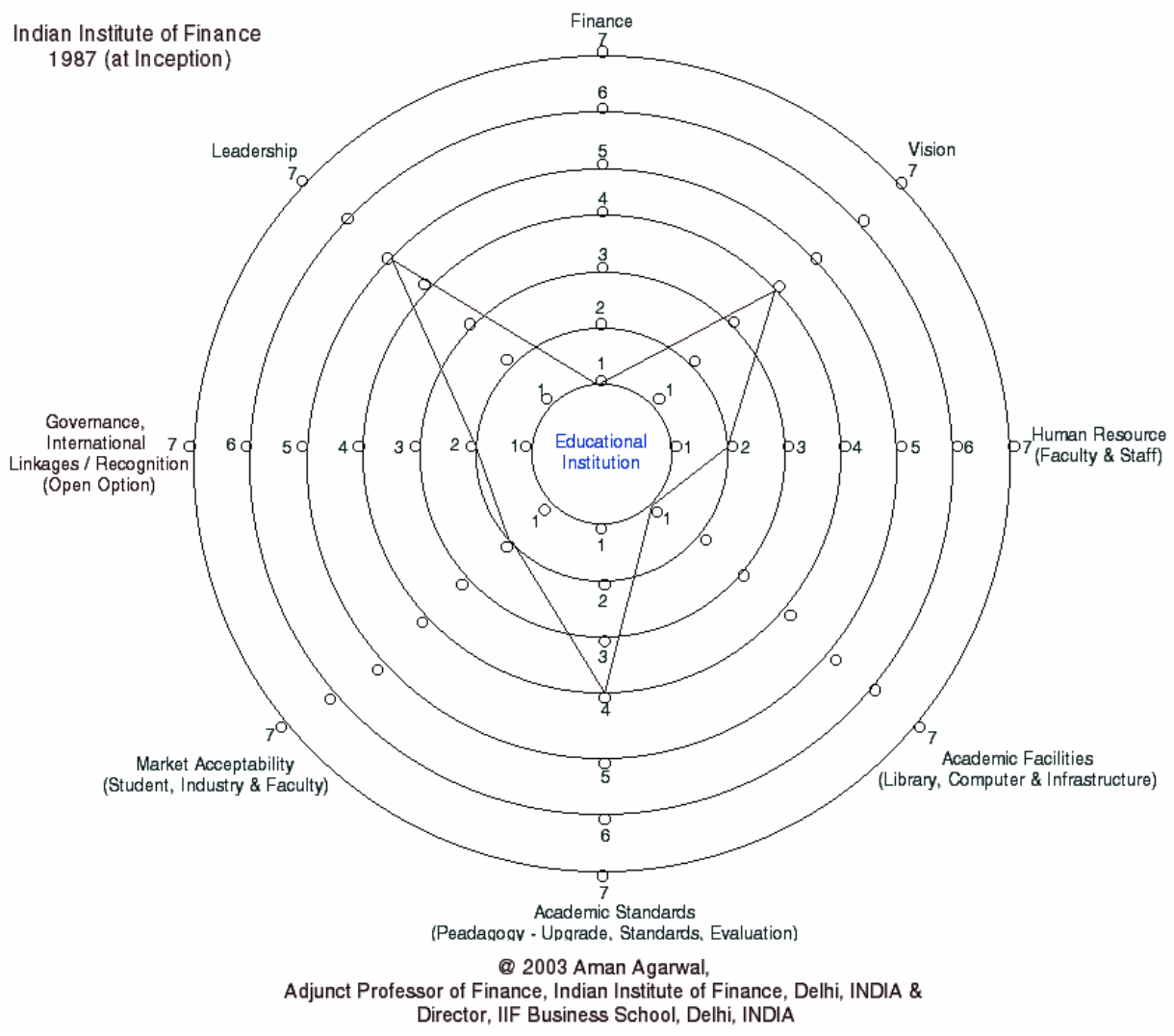

6. Invited by universities, international organisations and governments to set up educational Institutions, initiate MBA programmes, conduce research studies and organise international conferences. Has provided 
human resources and developed MBA programmes for over 100 institutions worldwide.

7. The library is housed with over 55000 books in the area of finance and accounting and receives over 700 technical journals (over 250 from abroad). The library also acts as a depository library for various international agencies such as IMF, UNCTAD, WIDER and many others including over 20 Central banks globally. Has over 120 doctoral dissertations, 3000 company reports.

\section{Figure 15: Indian Institute of Finance 1992 (After 5 years)}

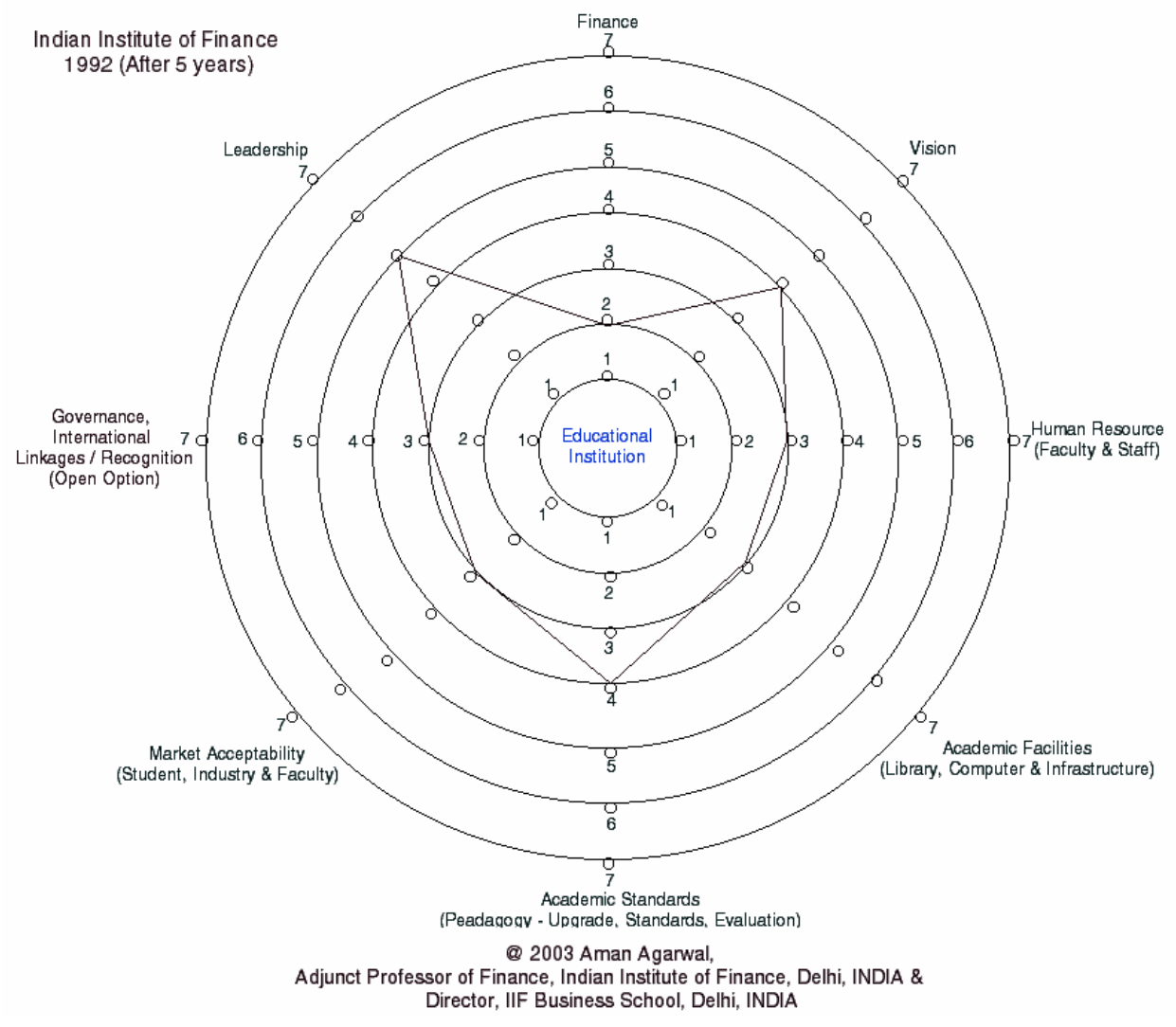

8. Receives over 12,000 interested applicants. Over 3200 are interviewed for 120 seats at the institute for the regular programmes.

9. For Finances IIF is a self sufficient and self reliant Institution

10. International Collaborations and Linkages in every part of the world. 
11. The students are selected from all over India with all backgrounds. Most of the candidates are with technical backgrounds or with 3 to 7 years average experience or with a pre-Master's degree. On an average $20 \%$ of the class is University/College Toppers.

12. The institute has $100 \%$ placement. The average salary in Indian and MNC companies for last two years has been Rs. 20,000 with minimum being Rs. 15,000 and maximum Rs. 45,000.

13. The institute has a 1:4 Teacher-Student ratio (including visiting professors) and also the same ratio is there for Student-Computers ratio.

14. Unique and the only institute of its kind in India.

15. It has highest per capita journals and books in the country amongst all management Institutes including IIMs.

16. Linkages with Industry and Government - over 10000 executives and government officials trained by IIF faculty.

Figure 16: Indian Institute of Finance 1997 (10 years of Success)

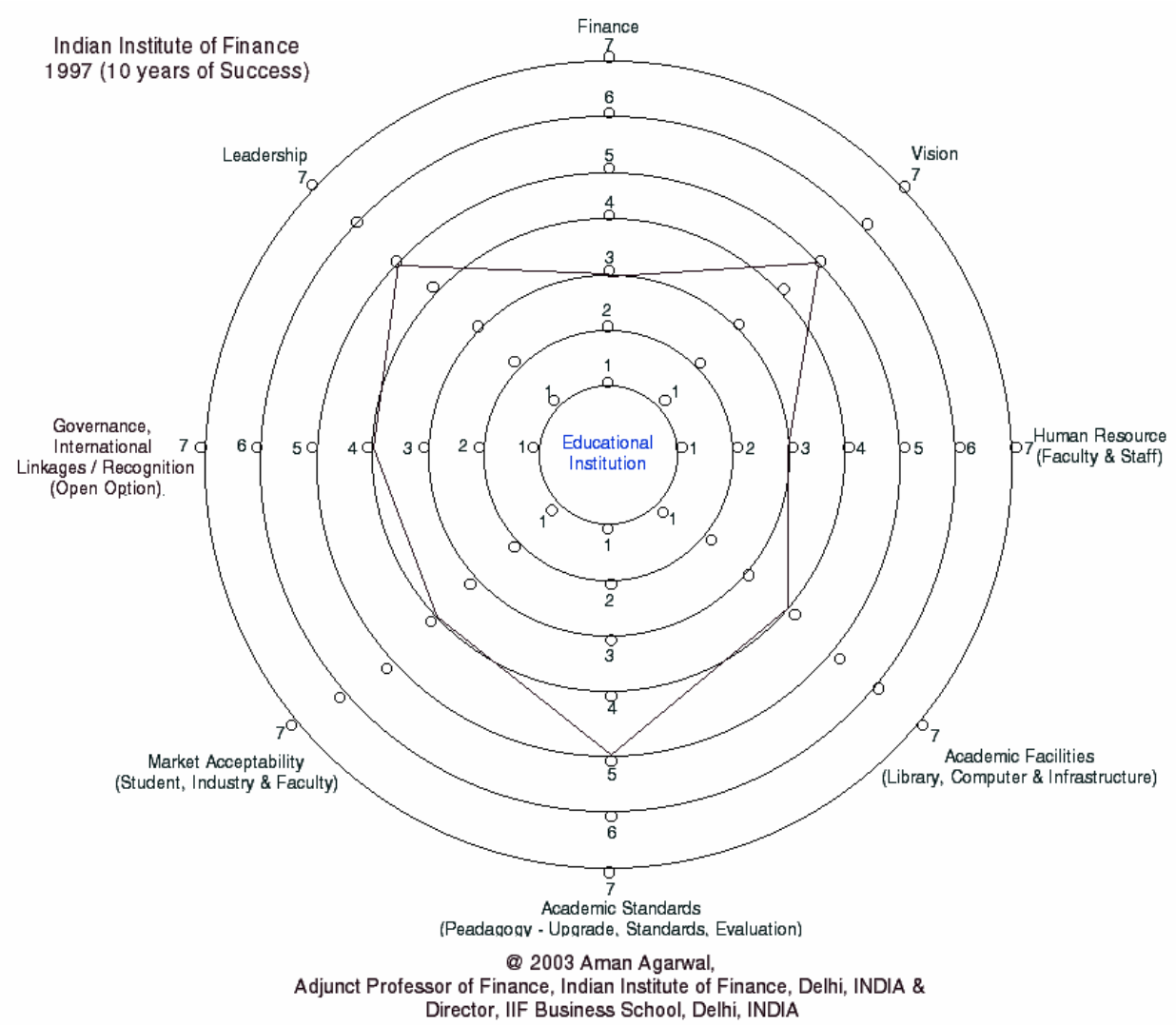


Recent Ranks have placed IIF as THE Best NICHE Business School in FINANCE in India by Outlook 2003, 2002; 21st for Best Placements and Admissions by Indian Management (AIMA) 2003; 24th for Best Placements with Moderate Fee by Management Refresher 2002; 27th for GOVERNANCE by Indian Management (AIMA) 2002; 26th for Intellectual Capital by Indian Management (AIMA) 2003; 27th WORLDWIDE amongst 79 Finance Institutions by American Statistical Association 2002. Some of the other organisations included in rating are Ohio`s states Virtual Finance Library, Financial Databases Directory, Federal Reserve Bank of Chicago, Korea Stock Exchange, Harvard-MIT Data Center, University of Maryland Economic data library, New York Stock Exchange, OECD, CNN, World Bank, Nasdaq Market Data, NBER, Morgan Stanley Capital International and IFC etc.; 40th WORLDWIDE among Finance, Macro, Labour \& Micro Economic Institutions for providing financial information and database by American Statistical Association (B\&E Datalinks) 2002.

Figure 17: Indian Institute of Finance 2002 (15 years of Growth)

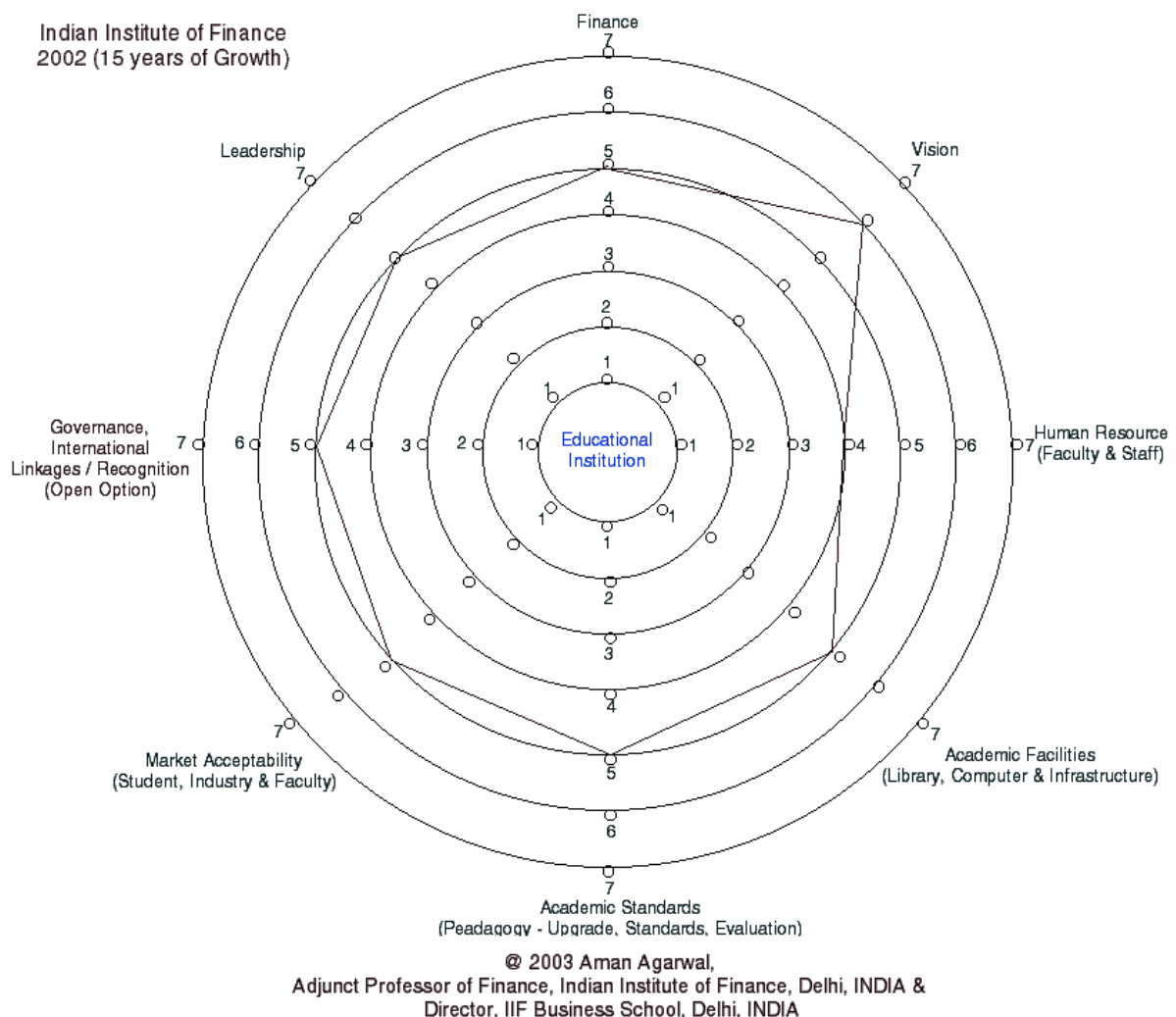




\section{Conclusion}

Organisations be they governmental or non-governmental are not and cannot be developed in years. It takes decades to develop a worthwhile institution in terms of physical infrastructure, human resources, academics, research and innovation, technical facilities, faculty, ethos, organisational culture and brand equity. An appropriate mix of experts on committees from government and non-government institutions needs to be utilised to lay a path for the new millenium into the next phase of excellence.

The quality of product, education and governance can best be maintained not through norms and standards fixed for physical facilities (which may be necessary to ensure stability) but through self-governing rules and regulation of the society/market mechanism. For this it is necessary that there is appropriate regulation and control at the entry point as well as exit. These need to be formulated within an institution and at the governmental level or via associations/chambers such as FICCI, CII, PHDCCI, IOD and others.

It is commendable that various chambers in India have initiated steps and brought forth a National Action Plan to be sent to the Central Government for enhancement, enrichment and growth of education and other sectors in India. Apart from the above, we would such as to mention that AICTE and MHRD have not paid any attention to foreign universities/institutions operating in India either independently or jointly with Indian institutions. Some of such foreign institutions do not have proper credentials. It is suggested that AICTE or MHRD needs to look into this issue on an urgent basis. Fortunately, this section for corporations has been well addressed and is under correction based on market performance since the set-in of the New Economic Order from 1991. Also, nodal agencies such as SEBI, Statutory Authorities, AICTE and UGC need to introduce transparency and accountability in its functioning so that more people have greater appreciation than criticism for their working. It should play a more constructive role of a regulator ensuring that good governance prevails and is encouraged and not that bad boys get rewarded and good ones punished, through a proper monitoring mechanism. These steps would initiate progressive growth, good governance and development in the organisations and the nation.

The models suggested would enable and empower an organisation to self-assess and formulate a route for good governance and growth-orientation. 


\section{References}

Agarwal J.D. "Achieving Excellence in Management Education", keynote speech at the International Conference on $26-28^{\text {th }}$ July 2002, Rajasthan Vidyapeeth (deemed) University, Udaipur, India.

Agarwal J.D., "Challenges for Management Education in the $21^{\text {st }}$ Century", Business Perspective, Vo1 II No 1, January-June 2000.

Agarwal, Aman, "Redefining the Management Statement", Indian Express, February 28, 2002.

Agarwal, Aman, Muhammad Rao Aslam (Pakistan), Namita Datta (India), Hettiarchchige Don Bernard S. Perera (Sri Lanka), Tshewang Norbu (Bhutan), Venkiteswaran Ramakrishnan (India), "Impact of Governance on Economic Development in South Asian Region" Finance India, XVI No 2, June 2002, presented at Columbia University, New York, USA, (November 2000).

AICTE, "Workshop on Quality Improvement of Management Education", November 21, 1997, All India Council of Technical Education.

Chauhan, C. P. S, "Higher Education in India: Challenges of Global Trends", University News, Vol. 40 No 17, April 29-May5, 2002.

Danak, D. J. Management of Education Organisation”, University News, Vo1. 39 No 23, June 4-10, 2001.

Gregory, S., "Restructuring Higher Education Incorporating National Service”, University News, Vo1. 40 No. 8, May 6-12, 2002.

Kanri, Hoshin, “Total Quality Management”, Integrated Quality Dynamics, http://www.iqd.com.

Ocampo, Roberto F. de. "Breaking Traditional Boundaries in Asia", paper presented at Global Forum for Management Education 2002, Bangkok, Thailand, June 10-12, 2002.

Patil, V. K., P.N. Sharma and A.S.R.A.S. Sastri. "Education in the Context of the Changing World", University News, Vol. 40 No 17, April 29May5, 2002. 
Pillai, Latha and B.S. Ponmudiraj, "2002: The year of Quality in Higher Education”, University News, Vo1. 40 No 31, August 5-11, 2002.

Siddique, M Akhtar, "Faculty Development for Excellence in Higher Education”, University News, Vol. 40 No. 8, May 6-12, 2002.

The World Bank Report, "Indicators of Governance and Institutional Quality", The Governance and Public Sector Reform Group, The World Bank, Washington DC, USA.

Zivney, Terry L. \& William J. Bertin, "Publish or Perish: What the competition is Really Doing”, The Journal of Finance, Vol. XLVII No 1, March 1992. 